\title{
PENGARUH KANDUNGAN PROTEIN DALAM PAKAN TERHADAP PERTUMBUHAN IKAN NAPOLEON, Cheilinus undulatus
}

\author{
Neltje N.Palinggi, Naftali Kabangnga, dan Aris G. Mangawe
}

\begin{abstract}
ABSTRAK
Penelitian ini bertujuan untuk mengetahui pengaruh kandungan protein dalam pakan terhadap pertumbuhan ikan napoleon, Cheilinus undulatus. Kandungan protein pakan yang dicoba adalah $25 \%, 30 \%, 35 \%, 40 \%, 45 \%$, dan $50 \%$. Ikan-ikan napoleon berbobot $263,82 \pm 9,28 \mathrm{~g}$ dipelihara dalam keramba jaring apung ukuran $1 \times 1 \times 1,2 \mathrm{~m}^{3}$ dengan kepadatan 7 ekor/keramba. Percobaan menggunakan rancangan acak lengkap dan masing-masing perlakuan dengan tiga ulangan. Hasil pengamatan menunjukkan bahwa pemberian pakan dengan kandungan protein $40 \%$ memberikan pertambahan bobot paling tinggi yaitu $74,8 \mathrm{~g}$ dengan laju pertumbuhan harian, rasio efisiensi protein, rasio konversi pakan, dan sintasan masing-masing $0,31 \% ; 0,40 \mathrm{~g} / \mathrm{g}$; $6,24 \%$; dan $85,5 \%$.
\end{abstract}

ABSTRACT: Effect of dietary protein on growth of Napoleon (Cheilinus undulatus). By: Neltje N. Palinggi, Naftali Kabangnga, and Aris G. Mangawe

The purpose of this study was to know the effect of feed protein content on the growth of napoleon, Cheilinus undulatus. The napoleon fish with initial body weight $263.82 \pm 9.28 \mathrm{~g}$ were reared in floating net cages size of $1 \times 1 \times 1.2 \mathrm{~m}^{3}$ with density of 7 fish/cage. They were fed daily for 12 weeks with diets containing different level of protein namely $25 \%, 30 \%, 35 \%, 40 \%, 45 \%$, and $50 \%$. The experiment was conducted in the completely randomized design with three replications. The result of experiment showed that the fishes fed with diet containing $40 \%$ protein gave the best biological respond. Weight gain, daily growth rate, protein efficiency ratio, feed conversion ratio, and survival rate of the fish were $74.8 \mathrm{~g}, 0.31 \%, 0.40 \mathrm{~g} / \mathrm{g}, 6.24 \%$, and $85.5 \%$, respectively.

KEYWORDS: $\quad$ protein, feed, napoleon (Cheilinus undulatus), growth, cage

\section{PENDAHULUAN}

Pertumbuhan ikan napoleon (Cheilinus undulatus) dalam keramba jaring apung sangat tergantung pada pasok pakan yang diberikan karena keterbatasan pakan alami yang dapat diperoleh. Pemberian pakan buatan yang memenuhi kebutuhan nutrisi (protein, lemak, karbohidrat, vitamin, dan mineral) ikan napoleon sangat dibutuhkan untuk mempertahankan dan membangun sel-sel tubuh, proses perkembangbiakan, dan pencegahan penyakit (Pascual, 1983).

Protein merupakan nutrien esensial untuk mempertahankan kehidupan dan memacu pertumbuhan (Halver, 1976; Boonyaratpalin, 1991). Kualitas protein bergantung kepada komposisi asam aminonya terutama asam amino esensial dan derajat kecernaannya (Alava \& Lim, 1983). Kebutuhan protein pakan berbeda untuk setiap stadia hidup ikan, di mana pada stadia larva membutuhkan protein pakan yang tinggi, tetapi sebaliknya lebih rendah pada stadia yang lebih besar (Lovell, 1980; Boonyaratpalin, 1991). Di samping itu setiap spesies ikan membutuhkan protein optimal yang berbeda pula.
Wong \& Chou (1989) melaporkan bahwa dalam pembesaran ikan kakap dibutuhkan protein pakan berkisar $40 \%-45 \%$ dan lemak $12 \%$. Sementara ikan kerapu, Epinephelus salmoides, berkisar $40 \%-50 \%$ (Chua \& Teng, 1980), baronang membutuhkan protein berkisar 35\% - 46\% (Basyarie \& Tanaka, 1986).

Tujuan penelitian adalah mengetahui pengaruh kandungan protein dalam pakan terhadap pertumbuhan ikan napoleon yang dipelihara dalam keramba jaring apung.

\section{BAHAN DAN METODE}

Wadah percobaan yang digunakan adalah jaring apung ukuran $1 \times 1 \times 1,2 \mathrm{~m}^{3}$ sebanyak 18 unit, diletakkan dalam satu unit rakit di laut. Perlakuan yang dicobakan adalah tingkatan kandungan protein dalam pakan yaitu $25 \%, 30 \%, 35 \%, 40 \%, 45 \%$, dan $50 \%$ dengan komposisi bahan seperti yang diperlihatkan pada Tabel 1. Masing-masing perlakuan dengan tiga ulangan yang disusun dalam rancangan acak lengkap. Pakan dibuat dalam bentuk pelet kering, dan hasil analisis proksimatnya disajikan pada Tabel 1 . 
Tabel 1. Komposisi dan analisis proksimat pakan percobaan

Table 1. Composition and proximate analysis of experimental diets

\begin{tabular}{lrrrrrr}
\hline & \multicolumn{6}{c}{ Kandungan protein (Protein content) (\%) } \\
\cline { 2 - 7 } \multicolumn{1}{c}{ Bahan (Ingredient) } & $\mathbf{2 5}$ & $\mathbf{3 0}$ & $\mathbf{3 5}$ & $\mathbf{4 0}$ & $\mathbf{4 5}$ & $\mathbf{5 0}$ \\
\hline Tepung ikan (Fish meal) (\%) & 27.4 & 34.7 & 42.0 & 49.3 & 56.6 & 63.9 \\
Tepung kedelai (Soybean meal) (\%) & 20.0 & 20.0 & 20.0 & 20.0 & 20.0 & 20.0 \\
Tepung terigu (Wheat meal) (\%) & 10.0 & 8.6 & 7.2 & 5.8 & 4.4 & 3.0 \\
Tepung tapioka (Cassava meal) (\%) & 10.0 & 9.1 & 8.2 & 7.3 & 6.4 & 5.5 \\
Dedak halus (Rice brand) (\%) & 16.0 & 12.9 & 9.8 & 6.7 & 3.6 & 0.5 \\
Minyak ikan (Fish oil) (\%) & 15.1 & 13.2 & 11.3 & 9.4 & 7.5 & 5.6 \\
Vitamin mix. a) & 1.0 & 1.0 & 1.0 & 1.0 & 1.0 & 1.0 \\
Mineral mix. b) & 0.5 & 0.5 & 0.5 & 0.5 & 0.5 & 0.5 \\
\hline Analisis proksimat (Proximate analysis) & & & & & & \\
- Protein kasar (Crude protein) (\%) & 26.12 & 31.5 & 36.81 & 41.88 & 46.75 & 50.13 \\
- Lemak kasar (Crude lipid) (\%) & 17.60 & 15.03 & 13.89 & 11.15 & 9.06 & 8.82 \\
- Serat kasar (Fiber) (\%) & 16.09 & 15.02 & 12.45 & 9.4 & 5.66 & 3.09 \\
- Abu (Ash) (\%) & 14.06 & 13.37 & 12.25 & 13.56 & 14.20 & 16.53 \\
- Air (Moisture) (\%) & 6.21 & 6.12 & 6.74 & 5.22 & 5.07 & 6.72 \\
- NFE (\%) & 19.92 & 18.96 & 17.86 & 18.79 & 19.26 & 14.71 \\
- Energi (Energy) (cal./100 g)) & 4,912 & 4,339 & 4,264 & 4,223 & 3.821 & 3.560 \\
\hline
\end{tabular}

a) Vit. A $(60.000 \mathrm{IU} / \mathrm{g})$; vit. D3 $(12.000 \mathrm{IU} / \mathrm{g})$; vit. E (120 mg/g); vit. K3 $(12,5 \mathrm{mg} / \mathrm{g})$; vit. B1 $(10 \mathrm{mg} / \mathrm{g}) ;$ vit. B2 $(25 \mathrm{mg} /$ g); vit. B6 $10 \mathrm{mg} / \mathrm{g})$; vit. B12 $(0,1 \mathrm{mg} / \mathrm{g})$; vit. C (150 mg/g); folic acid (5 mg/g); nicotinic acid (60 $\mathrm{mg} / \mathrm{g})$; pantothenate acid $(50 \mathrm{mg} / \mathrm{g})$; methionin $(50 \mathrm{mg} / \mathrm{g})$; biotin $(0,125 \mathrm{mg} / \mathrm{g})$

b) Calcium (32,5)\%; phosphor (10\%); iron (6 mg/g); manganese (4 mg/g); iodine (0,075 mg/g); copper (0,3 mg/ g); $\operatorname{zinc}(3,75 \mathrm{mg} / \mathrm{g})$

Ikan uji diperoleh dari hasil tangkapan di perairan Sulawesi Selatan dan sebelum percobaan dimulai terlebih dahulu dilakukan adaptasi terhadap lingkungan serta pakan uji. Padat tebar ikan uji adalah 7 ekor/ keramba, dengan bobot individu $263,82 \pm 9,28$ g/ekor. Ikan diberi pakan secara ad libitum dengan frekuensi dua kali sehari yaitu pagi dan sore hari. Parameter biologi yang diamati adalah pertambahan bobot tubuh, rasio konversi pakan, rasio efisiensi protein, dan sintasan. Sampling terhadap bobot ikan dilakukan setiap 4 minggu dengan masa pemeliharaan 12 minggu. Selama pemeliharaan berlangsung dilakukan pengamatan terhadap beberapa parameter kualitas air meliputi salinitas, suhu, $\mathrm{pH}$, oksigen terlarut, kecerahan, fosfat, nitrit, dan amonia, yang diukur pada pagi hari sekitar pukul 06.00 dan sore hari sekitar pukul 18.00 .

\section{HASIL. DAN BAHASAN}

Setelah 12 minggu pemeliharaan diperoleh perbedaan pertumbuhan ikan yang diberi pakan dengan kandungan protein berbeda. Hasil analisis statistik menunjukkan bahwa ikan uji yang diberi pakan dengan kandungan protein $40 \%$ memperlihatkan pertumbuhan yang nyata lebih tinggi
$(P<0,05)$ dibandingkan dengan pemberian protein $25 \%$, $30 \%, 35 \%, 45 \%$, dan $50 \%$ (Tabel 2). Ikan uji yang diberi pakan dengan kandungan protein $45 \%$ dan $50 \%$ memberikan perbedaan pertumbuhan yang nyata $(P<0,05)$ dengan ikan uji yang diberi pakan dengan kandungan protein $25 \%, 30 \%$, dan $35 \%$. Pertumbuhan ikan uji yang diberi pakan dengan kandungan protein $45 \%$ dan $50 \%$ serta antara $30 \%$ dan $35 \%$ tidak memberikan perbedaan. Bobot ikan uji yang diberi pakan dengan kandungan protein $25 \%$ memperlihatkan penurunan. Pemberian pakan dengan kandungan protein $40 \%$ memberikan pertambahan bobot sebesar $74,8 \mathrm{~g}$ dengan laju pertumbuhan harian $0,31 \%$. Laju pertumbuhan harian ini juga lebih tinggi dibandingkan dengan hasil percobaan sebelumnya yaitu $0,1 \%$ untuk pakan moist pellet dengan kandungan protein $30 \%$ (Palinggi et al., 1997); 0,25\% untuk pakan ikan rucah (Yuliansyah et al., 1993), dan $0,29 \%$ untuk pakan campuran ikan rucah dan pelet dengan kandungan protein $42 \%$ (Asmanelli \& Lamidi, 1994). Nilai laju pertumbuhan harian ini lebih rendah dari laju pertumbuhan harian ikan karnivora lainnya seperti ikan ekor kuning $(2,92 \%-4,07 \%)$ yang diberi pakan pelet dengan kadar protein 30\%-50\% (Ruchimat et al., 1997a). 
Pemberian pakan dengan kandungan protein $30 \%$ dan $35 \%$ memberikan pertumbuhan ikan uji yang hampir sama namun lebih rendah dari ikan uji yang diberi pakan dengan kandungan protein $40 \%, 45 \%$, dan $50 \%$. Hal ini disebabkan pemberian pakan dengan kandungan protein $30 \%$ dan $35 \%$ belum memenuhi kebutuhan protein ikan uji untuk tumbuh lebih baik. Ketidakseimbangan jumlah asam amino esensial sebagai penyusun protein dalam pakan dapat menyebabkan laju pertumbuhan ikan menurun. Hal ini disebabkan asam amino esensial yang jumlahnya rendah akan menjadi faktor pembatas bagi sintesa protein tubuh (NRC, 1983).

Pakan dengan kandungan protein $25 \%$ memberikan penurunan bobot sebesar 5,1 g; berarti pakan yang diberikan belum memenuhi kebutuhan protein untuk tumbuh. Menurunnya pertumbuhan atau kehilangan bobot ini adalah akibat perombakan protein yang ada dalam jaringan tubuh untuk mempertahankan fungsi utama dan menggantikan sel-sel yang telah mati (De Silva \& Anderson, 1995). Tidak adanya keseimbangan antara protein, lemak, dan karbohidrat juga akan menyebabkan menurunnya efisiensi penggunaan protein (Shiau \& Peng, 1993; Shimeno et al., 1996). Tabel 3 memperlihatkan bahwa ikan yang diberi pakan dengan kadar protein $25 \%$ kehilangan protein dalam dagingnya sebesar $8,8 \%$; dengan rasio efisiensi protein sangat rendah (Tabel 2).

Ikan napoleon yang diberi pakan dengan kandungan protein $45 \%$ dan $50 \%$ memberikan pertambahan bobot lebih rendah dari ikan yang diberi pakan dengan kandungan protein $40 \%$. Hal ini dapat terjadi karena ikan napoleon tidak mampu memanfaatkan secara efisien pakan dengan kandungan protein yang lebih tinggi. Kandungan protein yang tinggi dalam pakan membutuhkan energi tubuh yang tinggi untuk proses deaminasi sehingga akan mengurangi energi untuk pertumbuhan, akibatnya pertumbuhan ikan menjadi rendah (Jobling, 1985).
Nilai konversi pakan pada protein $40 \%$ adalah 6,24 lebih kecil daripada nilai konversi pakan lainnya. Nilai ini juga lebih rendah dibandingkan hasil percobaan pendahuluan di mana ikan napoleon yang diberi pakan moist pellet dengan kandungan protein 30\% memberikan rasio konversi pakan 49,18 (Palinggi et al., 1997), dengan pakan ikan rucah 21,2 (Yuliansyah et al., 1993), dan pemberian pakan campuran ikan rucah dan pelet dengan kandungan protein $42 \%$ nilai rasio konversi pakan adalah 12,2\% (Asmanelli \& Lamidi, 1994). Nilai konversi pakan ikan napoleon pada percobaan ini cukup besar dibandingkan dengan ikan karnivora lainnya, seperti ikan "dentex" (Dentex dentex L.) dan ikan kakap putih (Lates calcarifer) di mana konversi pakan masing-masing adalah 1,9; 1,2; dan 1,7 (Tibaldi et al., 1996; Williams \& Barlow, 1996; Williams et al., 1997;1999). Dari hasil ini terlihat bahwa ikan napoleon termasuk ikan yang pertumbuhannya lambat.

Dari nilai rasio efisiensi proteinnya, ikan yang diberi pakan dengan kandungan protein $40 \%$ dapat memanfaatkan protein lebih baik daripada perlakuan lainnya. Oleh karena itu, dapat memberikan pertumbuhan yang baik pula bagi ikan tersebut, karena protein merupakan nutrien esensial bagi pertumbuhan (Halver, 1976; Boonyaratpalin, 1991). Hal ini ditunjang dengan hasil analisis proksimat daging ikan sebelum dan sesudah percobaan (Tabel 3) di mana pada perlakuan pakan dengan kandungan protein $40 \%$ diperoleh penambahan kadar protein dalam daging ikan napoleon terbanyak yaitu $4,37 \%$. Nilai rasio efisiensi protein ini lebih rendah dari nilai rasio efisiensi protein ikan karnivora lainnya, seperti ikan kerapu (Epinephelus malabaricus) dan ikan ekor kuning (Seriola quinqueradiata) dengan nilai rasio efisiensi protein masing-masing $1,92 \mathrm{~g} / \mathrm{g}$ dan $1,13 \mathrm{~g} /$ g (Houng-Yung \& Jia-Chang, 1994; Ruchimat et al., 1997b).

Tabel 2. Pertambahan bobot, laju pertumbuhan harian, sintasan, rasio konversi pakan, dan rasio efisiensi protein

Table 2. Weight gain, daily growth rate, survival rate, feed conversion ratio, and protein efficiency ratio

\begin{tabular}{lcccccc}
\hline \multirow{2}{*}{ Peubah (Variables) } & \multicolumn{5}{c}{ Kandungan protein (Protein content) (\%) } \\
\cline { 2 - 7 } & $\mathbf{2 5}$ & $\mathbf{3 0}$ & $\mathbf{3 5}$ & $\mathbf{4 0}$ & $\mathbf{4 5}$ & $\mathbf{5 0}$ \\
\hline Pertambahan bobot (Weight gain) (g) & $-5.1^{\mathrm{d}}$ & $2.0^{\mathrm{c}}$ & $11.6^{\mathrm{c}}$ & $74.8^{\mathrm{a}}$ & $35.3^{\mathrm{b}}$ & $37.3^{\mathrm{b}}$ \\
Laju pertumbuhan bobot harian (Daily growth rate) & $-0.02^{\mathrm{d}}$ & $0.01^{\mathrm{c}}$ & $0.05^{\mathrm{c}}$ & $0.31^{\mathrm{a}}$ & $0.15^{\mathrm{b}}$ & $0.16^{\mathrm{b}}$ \\
Sintasan (Survival rate) (\%) & $85.5^{\mathrm{a}}$ & $78.5^{\mathrm{b}}$ & $43.0^{\mathrm{b}}$ & $85.5^{\mathrm{a}}$ & $71.5^{\mathrm{ab}}$ & $85.7^{\mathrm{a}}$ \\
Rasio konversi pakan (Feed conversion ratio) & $57^{\mathrm{d}}$ & $38.79^{\mathrm{c}}$ & $26.29^{\mathrm{b}}$ & $6.24^{\mathrm{a}}$ & $9.55^{\mathrm{a}}$ & $7.11^{\mathrm{a}}$ \\
Rasio efisiensi protein (Protein efficiency ratio) (g/g) & $-0.05^{\mathrm{c}}$ & $0.02^{\mathrm{bc}}$ & $0.06^{\mathrm{bc}}$ & $0.40^{\mathrm{a}}$ & $0.18^{\mathrm{b}}$ & $0.22^{\mathrm{b}}$ \\
\hline
\end{tabular}

Angka rata-rata dalam baris dengan notasi huruf yang berbeda menunjukkan perbedaan yang nyata $(P<0,05)$ Mean values in rows with different notations indicate statistically significantly different $(P<0.05)$ 
Tabel 3. Analisis proksimat ikan percobaan

Table 3. Proximate analysis of experimental fish

\begin{tabular}{|c|c|c|c|c|c|c|c|}
\hline \multirow{3}{*}{ Parameter } & \multicolumn{7}{|c|}{ Kandungan protein (Protein content) (\%) } \\
\hline & \multirow{2}{*}{$\begin{array}{c}\text { Sebelum penelitian } \\
\text { Before experiment }\end{array}$} & \multicolumn{6}{|c|}{ Sesudah penelitian (After experiment) } \\
\hline & & 25 & 30 & 35 & 40 & 45 & 50 \\
\hline Protein kasar (Crude protein) & 79.75 & 70.97 & 73.54 & 80.44 & 84.12 & 82.32 & 82.45 \\
\hline Lemak kasar (Crude lipid) (\%) & 0.99 & 0.57 & 0.53 & 0.21 & 0.28 & 0.40 & 0.50 \\
\hline Serat kasar (Fiber) (\%) & 0.65 & 3.58 & 3.10 & 2.44 & 1.50 & 1.20 & 1.45 \\
\hline Abu $($ Ash $)(\%)$ & 8.14 & 7.67 & 7.66 & 7.85 & 7.84 & 7.45 & 7.09 \\
\hline Air (Moisture) (\%) & 6.61 & 4.05 & 4.59 & 5.39 & 5.70 & 5.85 & 5.56 \\
\hline NFE $(\%)$ & 3.86 & 13.16 & 10.98 & 3.67 & 0.86 & 2.48 & 2.95 \\
\hline Energi (Energy) (cal./100 g) & 4,610 & 3,201 & 4,526 & 4,637 & 5,061 & 4,563 & 4,707 \\
\hline
\end{tabular}

Dari hasil analisis proksimat ikan uji terdapat peningkatan kandungan protein dalam tubuh ikan uji yang diberi pakan dengan kandungan protein di atas $35 \%$, di mana penambahan protein tertinggi diperoleh dari pemberian pakan dengan kandungan protein $40 \%$. Pada pemberian protein $25 \%$ dan $30 \%$ terjadi penurunan kandungan protein dalam tubuh ikan. Hal ini lebih memperjelas hasil yang diperoleh bahwa ikan napoleon membutuhkan protein $40 \%$ dalam pakannya untuk dapat tumbuh dengan baik. Hasil analisis proksimat ikan uji memperlihatkan ikan uji yang diberi pakan dengan kandungan protein $25 \%$ dan 30\% menghasilkan protein tubuh lebih rendah daripada ikan awal dan ikan uji yang diberi pakan dengan kandungan protein $35 \%, 40 \%, 45 \%$, dan $50 \%$. Terjadinya penurunan protein dalam tubuh ikan uji sebagai akibat adanya pemanfaatan komponen protein dalam tubuh ikan yang berlangsung secara terus-menerus

Tabel 4. Kualitas air selama percobaan

Table 4. Water quality during the experiment

\begin{tabular}{|c|c|c|c|c|c|c|}
\hline \multirow{2}{*}{ Parameter } & \multicolumn{6}{|c|}{ Kandungan protein (Protein content) $(\%)$} \\
\hline & 25 & 30 & 35 & 40 & 45 & 50 \\
\hline \multicolumn{7}{|l|}{ 1. Salinitas (Salinity) (ppt) } \\
\hline - pagi (moming) & $18--33$ & $18--33$ & $18--33$ & $18--33$ & $18--33$ & $18--33$ \\
\hline - sore (aftemoon) & $18--33$ & $18-33$ & $18--33$ & $18--33$ & $18--33$ & $18-33$ \\
\hline \multicolumn{7}{|l|}{ 2. Suhu (Temperature) $\left({ }^{\circ} \mathrm{C}\right)$} \\
\hline - pagi (morning) & $17.9--26.3$ & $17.6--26.3$ & $17.6--26.4$ & $17.8--26.3$ & $17.6--26.2$ & $17.6--26.2$ \\
\hline - sore (afternoon) & $12.0--27.8$ & $11.7--27.7$ & $11.7--27.5$ & $12.0--27.5$ & $12.0--27.6$ & $12.0--27.5$ \\
\hline \multicolumn{7}{|c|}{ 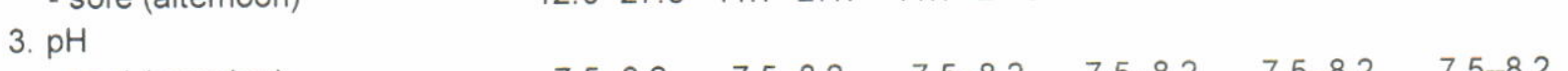 } \\
\hline - pagi (morning) & $7.5--8.2$ & $7.5-8.2$ & $7.5--8.2$ & $7.5--8.2$ & $7.5-8.2$ & $7.5--8.2$ \\
\hline - sore (aftemoon) & $7.5-8.2$ & $7.5--8.2$ & $7.5--8.2$ & $7.5-8.2$ & $7.5-8.2$ & $7.5--8.2$ \\
\hline \multirow{2}{*}{\multicolumn{7}{|c|}{$\begin{array}{l}\text { 4. Oksigen terlarut (Dissolved } \\
\text { oxygen) (mg/L) }\end{array}$}} \\
\hline & & & & & & \\
\hline \multicolumn{7}{|l|}{ - pagi (moming) } \\
\hline - sore (aftemoon) & $2.6--5.5$ & $2.7--5.6$ & $2.7--5.5$ & $2.6--5.5$ & $2.5--5.4$ & $2.5--5.4$ \\
\hline & $2.6--5.6$ & $2.3--5.6$ & $2.5--5.5$ & \multicolumn{3}{|c|}{ - pagi (moming) } \\
\hline - sore (aftemoon) & $0.1--5.0$ & $0.1--5.0$ & $0.1--5.0$ & $0.1--5.0$ & $0.1--5.0$ & $0.1--5.0$ \\
\hline 6. $\mathrm{PO}_{4}-\mathrm{P}(\mathrm{mg} / \mathrm{L})$ & $0.3--5.0$ & $0.3--5.0$ & $0.3--5.0$ & $0.3--5.0$ & $0.3--5.0$ & $0.3--5.0$ \\
\hline 7. $\mathrm{NO}_{2}-\mathrm{N}(\mathrm{mg} / \mathrm{L})$ & 0.0064 & 0.0064 & 0.0064 & 0.0064 & 0.0064 & 0.0064 \\
\hline \multirow[t]{2}{*}{ 8. $\mathrm{NH}_{4}-\mathrm{N}(\mathrm{mg} / \mathrm{L})$} & $<0.0004$ & $<0.0004$ & $<0.0004$ & $<0.0004$ & $<0.0004$ & $<0.0004$ \\
\hline & $0.1004-$ & $0.1167--$ & $\begin{array}{c}0.1185-- \\
0.1709\end{array}$ & $\begin{array}{c}0.1314- \\
0.1781\end{array}$ & $\begin{array}{c}0.1275-- \\
0.1799\end{array}$ & $\begin{array}{c}0.1203- \\
0.1691\end{array}$ \\
\hline
\end{tabular}


sementara jumlah protein yang masuk tidak memenuhi kebutuhan ikan mengakibatkan terjadi pengurangan komponen protein dalam tubuh ikan. Dalam kondisi rutin, komponen protein dimanfaatkan oleh aktivitas di dalam jaringan (sel), enzim, dan hormon (Hepher, 1990). Akibat aktivitas tersebut, maka protein dalam tubuh selalu berganti, yang lama rusak dan yang baru disintesis untuk menggantikannya. Dari Tabel 3 diperoleh bahwa semakin tinggi kandungan protein dalam tubuh ikan hasil penelitian cenderung semakin rendah kandungan lemaknya, bahkan diperoleh kandungan lemak ikan hasil penelitian lebih rendah dari kandungan lemak ikan sebelum penelitian. Hal ini mungkin disebabkan kadar lemak dalam pakan belum memenuhi kebutuhan ikan uji.

Sintasan tertinggi yang diperoleh selama percobaan berlangsung adalah $85,7 \%$ terjadi pada pemberian pakan dengan kandungan protein $50 \%$ dan yang terendah $43 \%$ diperoleh pada pemberian pakan dengan kandungan protein $35 \%$ (Tabel 2). Terjadinya kematian ikan napoleon disebabkan pada bulan November 1999 sampai dengan bulan Februari 2000 terjadi musim hujan disertai gelombang besar menyebabkan perubahan kualitas air, di mana suhu mencapai $17,6^{\circ} \mathrm{C}$ dan kecerahan $100 \mathrm{~cm}$ (Tabel 4), menyebabkan ikan malas makan dan akhirnya mati.

\section{KESIMPULAN}

Kandungan protein optimal yang direkomendasikan dalam pakan untuk pembesaran ikan napoleon adalah $40 \%$.

\section{DAFTAR PUSTAKA}

Alava, V.R. and C. Lim. 1983. The quantitative dietary protein requirements of Penaeus monodon juveniles in a controlled environment. Aquaculture, 30: 5361.

Asmanelli dan Lamidi. 1994. Pengaruh perbedaan kadar protein terhadap pertumbuhan ikan lemak, Cheillinus undulatus. J. Pen. Budidaya Pantai, 10(2): 51-60.

Basyarie, A. and H. Tanaka. 1986. Studies on rearing of rabbit fish-l: effect of different protein level on the growth of Siganus javus. Scientific Report of Mariculture Reseacrh and Development Project (ATA 192) in Indonesia. Sub Balai Penelitian Budidaya Pantai Bojanegara JICA, Serang, p. 10-16.

Boonyaratpalin, M. 1991. Nutritional studies on seabass (Lates calcarifer). In S.S. DeSilva (ed.). Fish Nutrition Research in Asia. Proceeding of the Fourth Asian Fish Nutrition Workshop. Asian Fish. Soc. Spec. Publ.5. Asian Fisheries Society, Manila. p. 33-42.

Chua, T.E. and S.K. Teng. 1980. Economic production of estuary grouper, Epinephelus salmoides Maxwell, reared in floating net cages. Aquaculture, (20): 187228.
De Silva, S.S. and T.A. Anderson. 1995. Fish Nutrition in Aquaculture. Chapman \& Hall, 2-6 Boundary Row, London SE1 8HN, UK, $319 \mathrm{pp}$.

Halver, J.E. 1976. The nutritional Requirement of Cultivated Warm Water and Coldwater Fish Species. Advance in Aquaculture, p. 574-580.

Hepher, B. 1990. Nutrition of Pond Fishes. Cambridge University Press, $388 \mathrm{pp}$.

Houng-Yung C. and Jia-Chang Tsai. 1994. Optimal dietary protein level for the growth of juvenile grouper, Epinephelus malabaricus, fed semipurified diets. Aquaculture, 119: 265-267.

Jobling, M. 1985. Growth. In P. Tytler (Ed.). Fish Energe-tics. New Perspectives. Croom Helm. London, 349 pp.

Lovell, R.T. 1980. Practical fish diets. In Fish Feed Technology. United Nation Development Programme, Food and Agriculture Organization of United Nation, Rome, p. 32-40.

National Research Council (NRC). 1983. Nutrient Requirements of Warmwater Fishes and Shellfishes. National Academy Press, Washington D.C., 102 pp.

Palinggi, N.N., Usman, dan A.G. Mangawe. 1997. Pengamatan pertumbuhan dan sintasan ikan napoleon yang diberi pakan buatan pada pemeliharaan di keramba jaring apung. Prosiding Simposium Perikanan Indonesia II, Hotel Sahid Makassar Ujung Pandang, 2-3 Desember 1997, $6 \mathrm{pp}$.

Pascual. 1983. Nutrition and Feeding of Penaeus monodon. Aquaculture Department, Southeast Asian Fisheries Development Center. Tigbauan Iloilo, Philippines, $12 \mathrm{pp}$.

Ruchimat, T., T. Masumoto, H. Hosokawa, and S. Shimeno. 1997a. Nutritional evaluation of several protein sources for Yellowtail (Seriola quinqueradiata). Bull.Mar.Sci.Fish., Kochi Univ., 17: 69-78.

Ruchimat, T., T. Masumoto, H. Hosokawa, Y. Itoh, and S. Shimeno. 1997b. Quantitative lysine requirement of yellowtail (Seriola quinqueradiata). Aquaculture, 158: 331-339.

Shiau, S.Y. and C.Y. Peng. 1993. Protein sparing effect of carbohidrate in diets for tilapia, Oreochromis niloticus. Aquaculture, 117: 327-334.

Shimeno, S., H. Hosokawa, and M. Takeda. 1996. Metabolic response of juvenile yellowtail to dietary carbohidrate to lipid rations. Fish. Sci., 62(6): 945949.

Tibaldi, E., P. Beraldo, L.A. Volpelli, and M. Pinosa. 1996. Growth response of juvenile dentex (Dentex dentex L.) to varying protein level and protein to lipid ratio in practical diets. Aquaculture, 139: 91-99.

Williams, K.C. and C.G. Barlow. 1996. Nutritional research in Australia to improve pelleted diets for grow-out barramundi, Lates calcanifer (Bloch). Proc. Aquaculture of Coral Fishes \& sustainable Reef Fisheries, Sabah, Malaysia, 4-8 December 1996, 12 pp.

Williams, K.C., C.G. Barlow, and L. Rodgers. 1997. Barramundi feeding and nutritional requirements. $Q D P /$ Recirculation Systems for Barramundi Aquaculture Seminar, 28 Nov. 1997, Nambour, 6 pp. 
Williams, K.C., C.G. Barlow, L. Rodgers, N. McMeniman, and W. Johnston. 1999. High performance grow-out pelleted diets for cage culture of Barramundi (Asian Seabass) Lates calcarifer. 1st International Symposium on Cage Aquaculture in Asia, 2-6 November 1999, Tungkang, Taiwan, 29 pp.

Wong, F.J. and R. Chou. 1989. Dietary protein requirement of early grow out seabass (Lates calcarifer) and same observation on the performance of two practical formulated feeds. Singapore Joumal of Primary Industries. The Primary Production Development, 17(2):134 pp.

Yuliansyah, H., D. Sipahutar, Lamidi, dan Muchari. 1993. Pertumbuhan dan kelangsungan hidup ikan lemak, Cheilinus undulatus dalam keramba jaring apung dan keramba jaring tancap. J. Pen. Budidaya Pantai, $9(4): 59-64$ 